\title{
Development of Web-Based Application in Population Administration System Using Scrum Framework
}

\author{
Ginanjar Wiro Sasmito ${ }^{1}$, M. Nishom ${ }^{2}$ \\ Department of Informatics Engineering \\ Polytechnic of Harapan Bersama \\ Tegal, Indonesia \\ \{anjar.dosen@gmail.com\}\{m.nishom.undip@gmail.com\}
}

\begin{abstract}
There are two methods of collecting data of population in Indonesia, they are: population census which conducted by the Central Statistics Agency using data sampling techniques, and the population data record which is conducted by the Population and Civil Registry Office during registering the ID number and family card. Differences in data collection method will potentially cause different result between two institutions; this will be a serious problem regarding to the validity and accuracy of population data. The population data of e two institutions are commonly used as a basis for making policies regarding beneficiaries for the poor, recipients of educational assistance, determining voting rights in elections and etc. The solution is to produce a website-based computer application platform to record population data by a bottom up method, which can be used by both institutions. The web application makes population data into a single data and eliminates data redundancy; it is also can be updated fast and real time. The web application is developed by implementing the Scrum framework, and only takes 30 days to complete the project. SUS examined the usability of this web application and the result is $83.5 \%$.
\end{abstract}

Keywords: Web Applications, Population, Scrum

Received: 2 July 2019, Revised 11 September 2019, Accepted 25 September 2019

(C) 2019 DLINE. All Rights Reserved

DOI: $10.6025 /$ ijwa/2019/11/4/125-135

\section{Introduction}

There are around 108 billion people who have lived on Earth, which means that the current population size reaches $6.5 \%$ of the total number of people who have been born [1]. Global human population growth reaches around 83 million a year [2] or 1.1\% a year. The global population has grown from 1 billion in 1800, to 7,616 billion in 2018 [3]. It is predicted that this will continue to grow with a total population increase to 8.6 billion in mid-2030, 9.8 billion in mid-2050 and 11.2 billion in 2100 [4].

Indonesia is one of the countries with a high level of density and greatly contributes to world population growth [5]. In which 2017 the total population was more than 261 million people spread in 34 provinces with a population growth rate of $1.34 \%$ [6]. The large population growth in Indonesia will occur over the next 25 years even though the rate of increase will be slowing down; this is especially will happen on Java, even though the area of Java is only 7\% of the land area of Indonesia [7]. The population density will affect on several things, such as: distribution of populations near to the coastline will affect the risk of rising sea levels [8,9], habitat fragmentation [10] and determinants of the spread of infectious diseases [11], in addition, rapid and erratic population growth also influences in determining mitigation [12] and changing global policy such as: land use, energy use, and

International Journal of Web Applications Volume 11 Number 4 December 2019 
emissions use [13], therefore good planning is necessary to minimize or even avoid these impacts, one of the efforts that must be conducted is to manage population data optimally. The objectives of managing population data are increasing service effectiveness, ensuring data accuracy, guaranteeing the single identity and document of population [14]. To make these goals a reality, accurate and real-time data collection techniques are needed, as well as good data integration between population data administrators at the central, provincial and city / district levels. Classification of population data consists of several things, they are: population based on age, gender, occupation, religion, productive age and unproductive age, recent education, and income, it is also required data on population numbers and growth for each region [15], both for the scope of the state, province, and city / district area.

There are two methods of collecting data of population in Indonesia, they are: population census which is conducted by the Central Statistics Agency using data sampling techniques [16], and the population data record which is conducted by the Population and Civil Registry Office during registering the ID number and family card [17]. The Differences in data collection method will potentially cause the different result between two institutions; this will be a serious problem regarding to the validity and accuracy of population data. Moreover the two institutions are the main references of population data. The population data of the two institutions are commonly used as a basis for making policies regarding beneficiaries for the poor, recipients of educational assistance, determining voting rights in elections and etc. The population data from both institutions are presented in pdf and table format.

Based on these problems, the solution is to produce a website-based computer application platform to record population data by a bottom up method. namely: the head of the RT (Neighbourhood Association) inputs population data with variables that have been determined by the government, then validated by the head of the RW (Neighbourhood Association), Village, and District for further validation and verification by the Department of Population and Civil Registration. The validated and verified data by the Office of Population and Civil Registration can be directly taken and utilized by the Central Statistics Agency as a mutually integrated data and presented with high validity and accuracy, since data integration is a way to minimize redundancy and duplication of data [18], so the data which is processed or presented is single data. In addition to understand the presented data more easily, the visualization of data in the form of graphs or charts is displayed in the computer application platform as part of the solution to the existing problems.

\section{Related Work}

A research has resulted in a website application which is developed to visualize the macromolecular structures, by utilizing modern web technologies: WebGL or NGL Viewer, which is able to provide scaled molecular graphs. Generally the resulting web application offers a comprehensive molecular visualization through the user interface, so it can easily access and take advantage of available structural data [19].

Web application that adopts semantic web technology is applied to describe the ontology application management framework; it is called OAM (An Ontology Application Management). The framework focuses on providing data and application templates that can easily be used and configured for users without having expertise in programming. There are three forms of template that have been generated, they are: ontology mapping database configuration, recommendation rules, and application templates. The case studies which are used in the application of the framework are: introduction of the smart home domain activities, and clinical support systems of Thalassemia [20].

In analyzing differential gene expression (DGE) usually uses a variety of devices, such as: statistical software, spreadsheets, or special ad-hoc algorithms. Therefore in this study a web-based application has been produced with the name: DEIVA.This application is a freeware and open-source application that allows finding and identifying single or multiple genes quickly, interactively and intuitively. DEIVA is designed for a very large number of users and data sets. Comparing with other software, DEIVA has a unique combination of design decisions that allow inspecting and analyzing to DGE statistical test results with user friendly features [21].

Web applications are also applied in estimating carbon footprint in organic agriculture. Organic farmers often use complex management practices in encouraging positive impacts on the environment. While many tools have been used in estimating environmental use, but only a few are able to handle the complexities of organic farming well. Therefore an online web application has been developed called Ofoot which has been implemented in the Pacific Northwest to estimate the carbon footprint of 
organic agriculture and assist to evaluate the potential environmental benefits. Ofoot uses a cradle-to-gate carbon calculator and biophysical models based on the process of planting and environmental management. Ofoot serves as an aid for management decisions in organic farming [22].

A web application has also been developed to estimate the total cost in electric discharge from experimental parameters set in the reactor such as: JUPITER-MOSMET [1-5], which is used to modify metal and non-metal surface types in solid substrates by highvoltage hybrid electric discharge and low pressure [6-13].The developed web application can be used anytime, anywhere and without special requirements, it only requires an internet connection and current pulse data to be processed. Format data received by the system can be downloaded via the web application. Processing data obtained from the web application is very similar to the current pulses that are reported experimentally during the ignition of electricity, to ensure that the implemented web application works properly and correctly to estimate the total cost [23].

The application of the web application is also carried out for analytical visualization of smart city applications. In this study 4D canvas models and web-based applications have been produced for dynamic visualization of 3D geospatial data for better decision making in smart city applications. The 4D canvas in this study can be used both on desktop and multi-touch screens platforms, this application also allows easier integration of other geospatial simulation results, thus helping users explore interactively in 4D [24].

\section{Methodology}

In developing web applications that are applied to the population administration system in this study is using the Scrum framework. Scrum was developed by Jeff Sutherland in 1993 with the aim of becoming a development and management methodology that follows the principles of the Agile methodology [25]. Scrum is a framework which is used for software development projects and managing product or application development [26]. Scrum focuses on flexible strategies for developing software products, where the development team works to achieve common goals [26] [27]. Scrum has a complex process, in which many factors influence the final result [28]. The scrum framework consists of product guarantees, sprint planning meetings, sprint backlogs, sprint retrospectives, sprint reviews, and daily meetings which is conducted by team members to complete the project [29], while the intended team members are: product owner, Development Team and Scrum Masters [30]. In this study the Scrum framework scheme that is applied can be shown in the following figure 1 [31]:

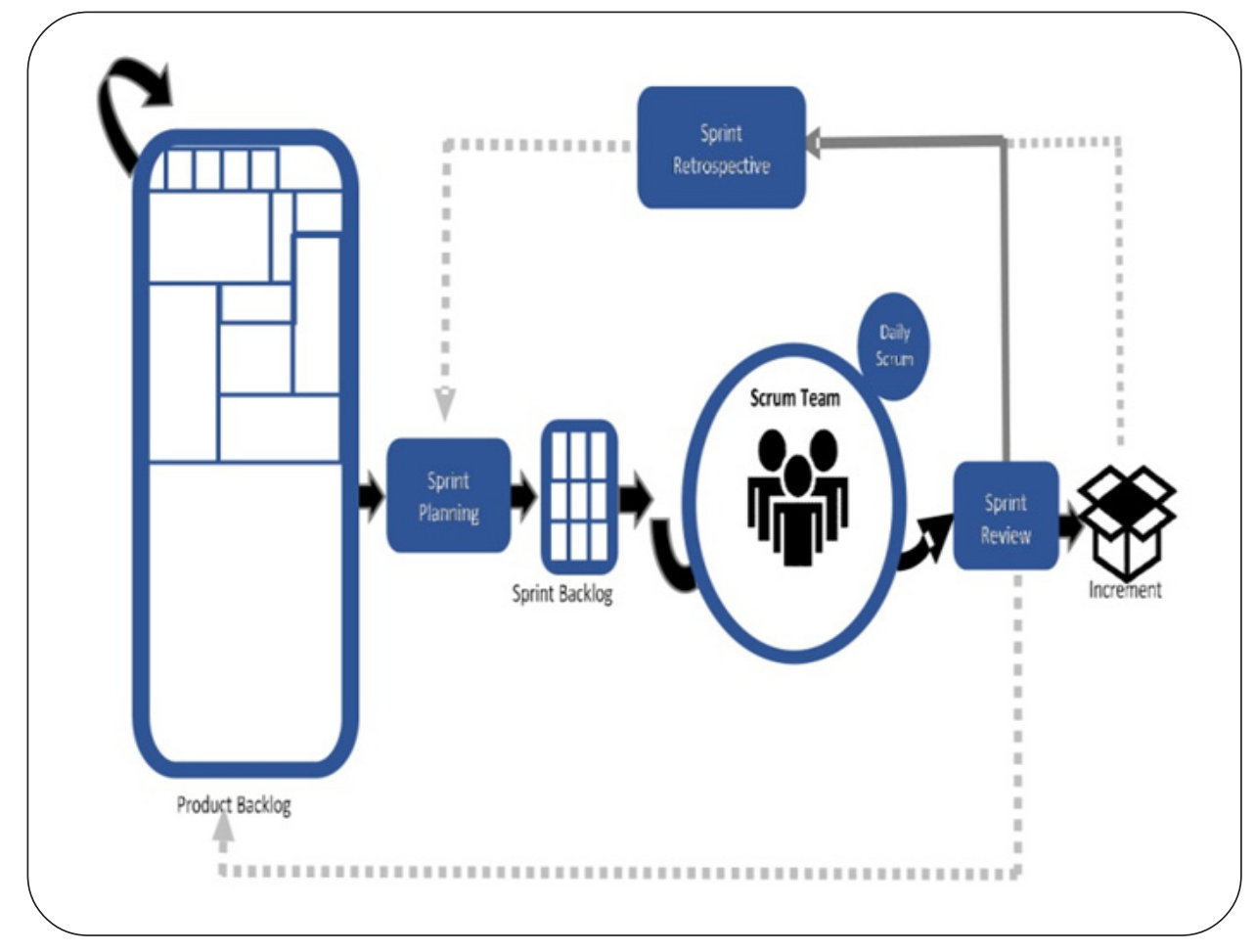

Figure 1. Scrum Framework 


\section{Result and Discussion}

\subsection{Web Design}

The design of web application development in population administration systems is made by using UML (Unified Modeling Language) which is a standard for designing object-oriented systems with a high level of complexity [32]. UML is used to determine, visualize, build and do documentation when establishing / developing application systems using certain programming languages [33]. In this study UML diagrams are illustrated using Use case diagram. This diagram is functionality provided by the system as a unit for interacting each other between units or actors [34] and Class Diagrams, in which are diagrams with static structures that able to illustrate the structure of a system by showing system classes, attributes, operations (methods), and relationships between objects [35].



Figure 2. Use case diagram 


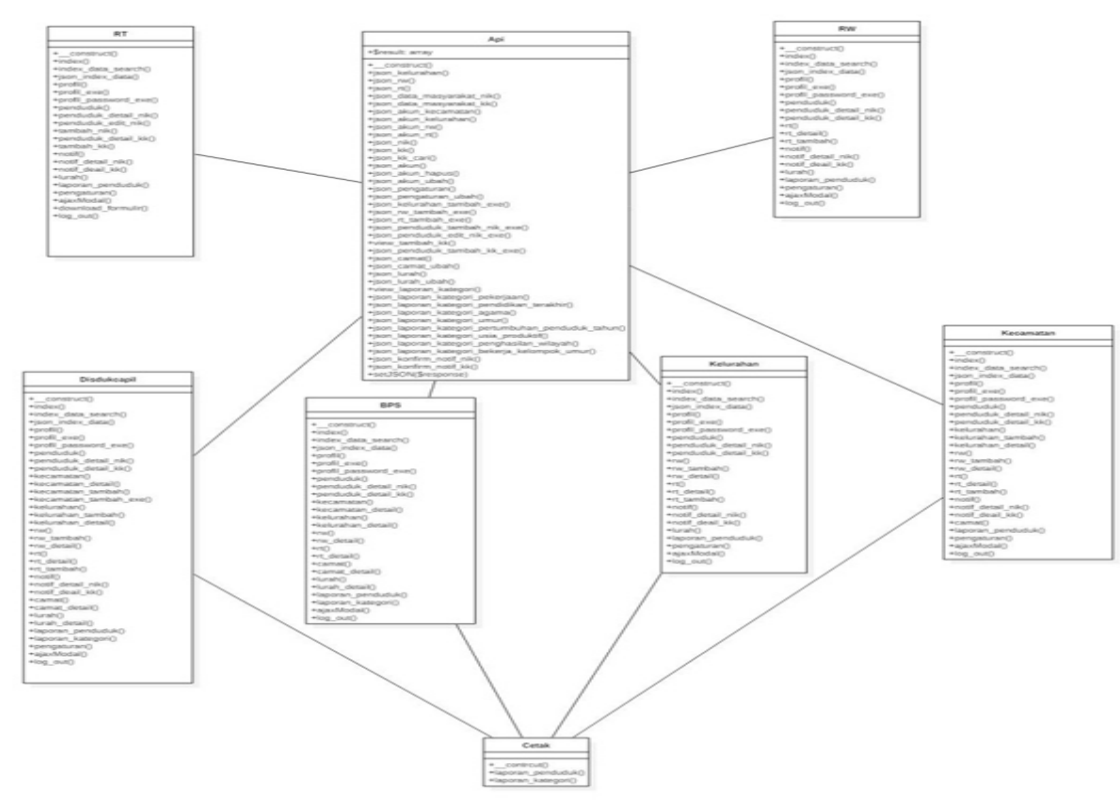

Figure 3. Class Diagram

\subsection{User Interface}

The user interface of web application that has been generated in this study is used for 6 administrator menus, such as menus for head of RT, head of RW, village office, sub-district, Department of Population and Civil Registration, and Central Bureau of Statistics. The web application is developed using the PHP programming language which is a server-side script programming language, it is designed for web development [36] with a database in the form of My SQL which is an open source RDBMS (Relation Database Management System) [37].The user interface can be seen in Figure 4 below:
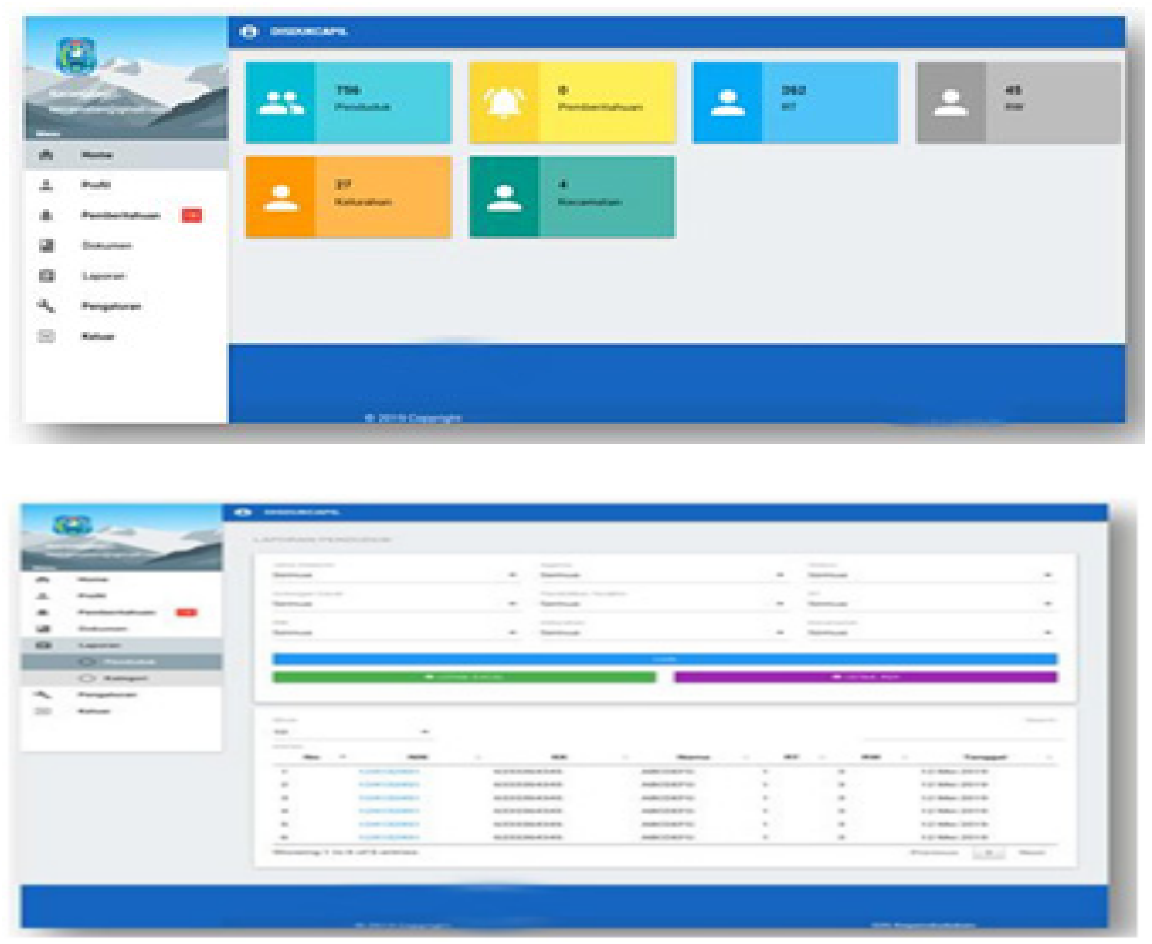

Figure 4. Display of Web Application 


\subsection{Discussion}

The development of a population administration web application is carried out with the Scrum framework, the explanation is as follows:

\begin{tabular}{|c|c|c|c|}
\hline ID & Product Backlog Item & Priorization & Estimate (Day) \\
\hline 1 & Problem Identification and Analysis & & 1 \\
\hline 2 & Description of Solution & & 1 \\
\hline 3 & Identification of Needs & & 1 \\
\hline 4 & $\begin{array}{l}\text { System Design and Prototyping(UML } \\
\text { Design, UI / UX Design) }\end{array}$ & & 3 \\
\hline 8 & $\begin{array}{l}\text { Testing(Software Testing using Black Box } \\
\text { and White Box Testing) }\end{array}$ & & 1 \\
\hline 9 & Testing(Usability Testing) & & 1 \\
\hline 5 & $\begin{array}{l}\text { Database Design and Creation(Database } \\
\text { Design and Creation with My SQL using } \\
\text { XAMPP) }\end{array}$ & & 5 \\
\hline 7 & $\begin{array}{l}\text { System-wide integration(Integration of } \\
\text { web application systems using databases, } \\
\text { and integration between administrator } \\
\text { menus) }\end{array}$ & & 3 \\
\hline 6 & $\begin{array}{l}\text { Coding in creating applications (Building } \\
\text { a web application with the PHP program } \\
\text { ming language in accordance with the ex } \\
\text { isting design and prototype) }\end{array}$ & & 10 \\
\hline 10 & $\begin{array}{l}\text { Application improvements and } \\
\text { refinements(After going through the pro } \\
\text { cess of integration and testing, then the } \\
\text { web application is repaired and refined to } \\
\text { avoid bugs / errors and to suit the needs } \\
\text { of the product owner) }\end{array}$ & & 3 \\
\hline 11 & $\begin{array}{l}\text { Release(After the application has been } \\
\text { integrated, tested, then repaired / refined } \\
\text { based on the needs of the product owner } \\
\text { and the product has been documented in } \\
\text { according to the initial agreement, then } \\
\text { the web application can be released) }\end{array}$ & & 1 \\
\hline & Total & & 30 \\
\hline
\end{tabular}

Table 1. Product Backlog 


\subsubsection{Product Backlog}

Product Backlog is a list of all the features, functions, needs, enhancements, and improvements that need to be applied to a product. Product Backlog aims to determine priority work in a sprint; this is determined by the Product Owner, Scrum Master, and Development Team. Product Backlog has to be conducted and has been arranged according to certain priorities. These items can be in the form of results and exploration of customer needs, functional and non-functional descriptions, as well as the things needed to release a finished product [38]. The Product Backlog is the responsibility of the product owner with the following details in table 1:

The Product Backlog in table 1 shows the priority order of work in the Scrum framework.

\subsubsection{Sprint Planning}

In this stage the tasks that will be conducted in the web application development project are formulated in a task meeting that will be carried out by the whole team, they are: the product owner, scrum master, and development team. The division of tasks and the flow can be explained in the following table 2 :

\subsubsection{Sprint Backlog}

The Sprint Backlog is an estimate of the functionality that will be available in the next iteration, and an important task that need to be conducted to deliver the functionality into pieces of product that are considered complete [39]. At this stage, the development team creates a picture of the real project that is being worked on, in accordance with the plan of product owner at the product backlog stage. This stage is conducted every time will do a sprint.

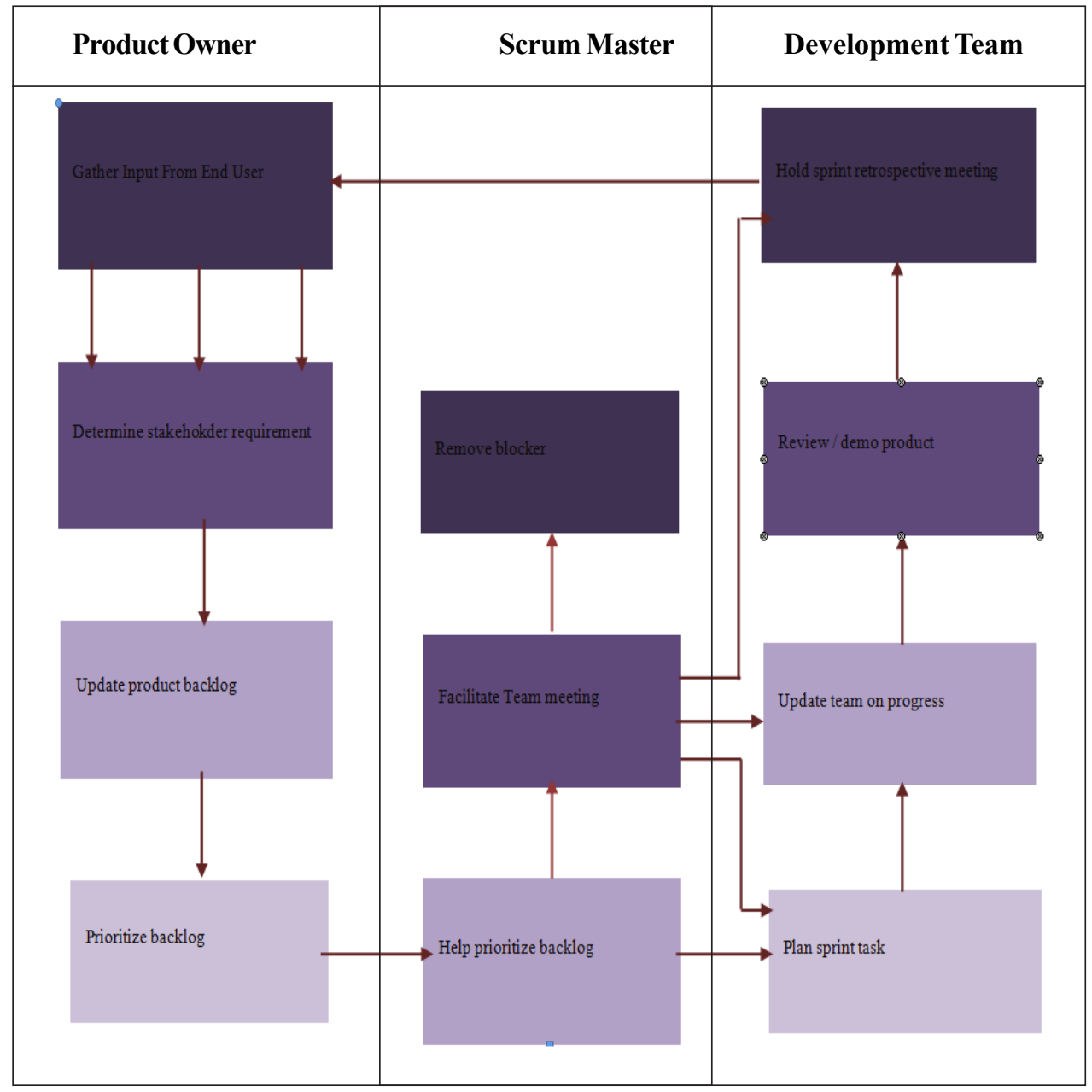

Table 2. Sprint Planning Meeting 


\subsubsection{Daily Scrum}

Daily Scrum is a stage when all members of the development team share the problems experienced and provide solutions to each other's problems, the Team also shares the results / progress of their work, including design and prototype of the application, database design and manufacturing, coding / programming, application integration, application testing, and application improvement / refinement. Daily scrum is carried out every day during the sprint.

\subsubsection{Sprint Review}

Sprint review a stage when every team member demonstrates the results of his / her work in a sprint. This stage is carried out after one sprint is completed. In this case all the team members demonstrate the project development of population administration web applications and evaluate each other then finally all team members' works are united and integrated.

\subsubsection{Sprint Retrospective}

The Sprint Retrospective is conducted at the end of each sprint. In this stage, the development team presents to product owner and scrum master about the scrum process that is being implemented in developing a population administration web application. The development team also presents the testing results of population web application using black box and white box and presents the user testing results using usability testing as a product evaluation technique with verifying to users [40]. There are five elements that are the main elements of usability testing. They are Usability, Efficiency, Effectiveness, Satisfaction and Accessibility [41]. The test is conducted by distributing the questionnaire randomly to head of RT, head of RW, village office employees, sub-district employees, Department of Population and Civil Registration employees, Central Bureau of Statistics employees, academics, and IT practitioners with a total of 8 respondents with 7 questions in which previously they are asked to use a web application according to the account provided.

\begin{tabular}{|l|l|l|l|l|l|l|l|l|l|c|}
\hline No & Question & \multicolumn{7}{|c|}{ Respondents' Score ( R ) } \\
\hline & & R1 & R2 & R3 & R4 & R5 & R6 & R7 & R8 & Score \\
\hline 1. & Q1 & 4 & 5 & 5 & 5 & 5 & 3 & 5 & 5 & 37 \\
\hline 2. & Q2 & 4 & 4 & 3 & 4 & 4 & 4 & 4 & 5 & 32 \\
\hline 3. & Q3 & 4 & 5 & 4 & 5 & 4 & 4 & 5 & 3 & 34 \\
\hline 4. & Q4 & 4 & 4 & 3 & 3 & 4 & 3 & 4 & 4 & 29 \\
\hline 5. & Q5 & 4 & 5 & 4 & 4 & 4 & 5 & 5 & 4 & 35 \\
\hline 6. & Q6 & 4 & 3 & 4 & 3 & 3 & 5 & 3 & 4 & 29 \\
\hline 7. & Q7 & 4 & 5 & 5 & 5 & 4 & 5 & 5 & 5 & 38 \\
\hline
\end{tabular}

Table 3. Calculation of Respondent Scores

The conversion results of the total score in table 3 are shown in the percentage; they are calculated by dividing total score to total maximum score of $x 100 \%$ :

$$
\text { Percentage }=\frac{234}{280} \times 100=83.5 \%
$$

The measuring instruments used are SUS (System Usability Scale) questionnaires. The result can be calculated by using formula: 
$Y=Q / S \times 100 \%$

$Q=$ Total scores of respondent for each question

$S=$ Total Maximum of respondent's scores

$Y=$ percentage scores

Then the average SUS scale calculation results for all distributed questions obtains a score $=82.1 \%$

After usability testing is complete, the product owner and scrum master provide suggestions and criticisms relating to the team's performance in implementing Scrum. Then the development team improves and perfects the population administration web application based on test results and suggestions from the product owner and scrum master.

\subsubsection{Increment}

Increment is the last step of the Scrum Framework. This stage is a result of completed work to support empiricism and it is can be inspected at the end of the Sprint. In this case every the sprint result, increment is a step to achieve the goal / vision. This stage the product owner also decides whether the project has been completed or not.

\section{Conclusion}

Based on the results of the completed research, it can be concluded that the process of developing a population administration web application using the Scrum framework only takes 30 days, since all scrum teams are involved in the process of completion, then data can be well integrated, the problems during application development is more quickly solved. The product of web application makes population data into a single data and eliminates data redundancy, besides that the process of updating population data also becomes fast and real time. The result of the usability testing using SUS also get $=83.5 \%$.

\section{References}

[1] As per 2011 Estimates from Carl Haub. (2011). How Many People Have Ever Lived on Earth ?. Population Reference Bureau.

[2] Population Division. Department of Economic and Social Affairs Population. 2019. World Population Prospects 2019 (Highlights). United Nation : New York

[3] Current World Population. World Population 2018. Worldometers. (Available : https://www.worldometers.info/world-population/)

[4] Gerland, Patrick. (2014). World Population Stabilization Unlikely This Century. Science. 346(6206), 234 - 237. DOI : 10.1126/ science. 1257469

[5] Kohler, Hans-Peter. (2015). Indonesian Perspectives. Population and Demography. Post 2015 Development Agenda..

[6] BPS. (2018). Statistical Yearbook of Indonesia 2018. Catalog : 1101001. BPS-Statistics Indonesia.

[7] Jones, Gavin, W. The 2010 - 2035 Indonesian Population Projection (Understanding the Causes, Consequences, and Policy for Population and Development). UNFPA.

[8] Hauer, M. E. (2015). Sea Level Rise and Sub Country Population Projections in Coastal Georgia Popul. Environ. $3744-62$

[9] Mc. Granahan. (2007). The Rising Tide: Assessing the Risk of Climate Change and Human Settlements in Low Elevation Coastal Zones Environ. Urban. 19 17-37

[10] Theobald, D. M., Crook, K. R., Norman, J. B. (2011). Assessing Effects of Land Use on Landscape Connectivity : Loss and Fragmentation of Western US Forest Ecol. Appl. 212445-58

[11] Caminade, C. (2014). Impact of Climate Change on Global Malaria Distribution. Proc. Natl Acad. Sci. USA 111 3286-91

[12] Scovronick, Noah. (2017). Impact of Population Growth and Population Ethics on Climate Change Mitigation Policy. PNAS. 12338-12343.114(46).

[13] Jones, B., O’Neill, B. C. (2016). Spatially Explicit Global Population Scenarios With the Shared SocioEconomic Pathway. 
Environ. Res. Lett. 11 (2016) 084003. IOP Publishing.

[14] Stephens, Matthew. (2001). A New Statistical for Haplotype Reconstruction from Population Data. AJHG. 68 (4) 978 - 989.

[15] Willems, Thomas. (2016). Population-Scale Sequencing Data Enable Precise Estimates of Y-STR Mutation Rates. AJHG. 98 (5).

[16] BPS (Statistics Indonesia). Available : https://www.bps.go.id/

[17] Ditjen Dukcapil. (Population and Civil Registration). Available : https://dukcapil.kemendagri.go.id/

[18] Kang, Wook, Tae., Hong., Hee, Chang. (2015). A Study on Software Architecture For Effective BIM/GIS-based Facility Management Data Integration. Automation in Construction. 54, June 2015. 25-38.

[19] Rose, A. S., Hildebrand, P. W. (2015). NGL Viewer : A Web Application for Molecular Visualization. Nucleic Acids Research, 2015. 43. Web Server Issue. doi : 10.1093/nar/gkv402

[20] Buranarach, Marut. (2016). OAM : An Ontology Application Management Framework for Simplifying Ontology- Based Semantic Web Application Development. International Journal of Software Engineering and Knowledge Engineering. 26 (01) $115-145$.

[21] Harshbarger, Jayson. (2017). DEIVA : A Web Application for Interactive Visual Analysis of Differential Gene Expression Profiles. BMC Genomics. ISSN : 1471-2164.

[22] Carlson, B. R. (2017). Development of a Web Application for Estimating Carbon Footprints of Organic Farm. Computers and Elctronics in Agriculture. vol 142 Part A, p 211-223.

[23] Vera-Rivera, F. H. (2016). Development of Web Application for Estimate the Total Charge In an Electric Discharge. Journal of Physics : Conference Series 687 (2016) 012058. IOP Publishing

[24] Murshed, Monjur, Syed. (2018). Design and Implementation of a 4D Web Application for Analytical Visualization of Smart City Applications. International Journal of Geo-Information. 7 (7).

[25] Pham, A. (2011). Scrum in Action Agile Software Project Management and Development. Boston, Mass., Course Technology PTR.

[26] Permana, Putu, A. G. (2015). Scrum Method Implementation In a Software Development Project Management. International Journal of Advance Computer Science and Application (IJACSA). 6(9).

[27] Mariyappan, Shalini. (2018). Enhancing Scrum Framework : A Case at a Multinational Company in Malaysia. International Journal of Engineering \& Technology.

[28] Qureshi., M. R. J., Sayid Isaac. (2015). Scheme of Global Scrum Management Software. I.J. Information Engineering and Electronic Business. DOI : 10.5815/ijieeb.2015.02.01

[29] Pino, F. J. (2010). Using Scrum to Guide the Execution of Software Process Improvement in Small Organizations. Journal of System and Software. 83(10) 1662 - 1677.

[30] Schwaber, Ken., Jeff Sutherland. (2017). The Scrum Guide, Scrum.Org. Retreived October 27, 2017.

[31] Morris, David. (2017). Scrum : An Ideal Framework from Agile Project in Easy Step. p 178-179. ISBN : 9781840787313.

[32] Bashir, R. S. (2016). UML Models Consistency Management : Guidelines for Software Quality Manager. International Journal of Information Management. 36(6), Part A. p 883-899.

[33] Ho-Quang., Truong. (2017). Practices and Perceptions of UML Use in Open Source Project. IEEE/ACM $39^{\text {th }}$ International Conference on Software Engineering : Software Engineering in Practice Track (ICSE-SEIP). DOI : 10.1109/ICSE-SEIP.2017.28

[34] Torre, Damiano. (2018). UML Diagram Synthesis Techniques : A Systematics Mapping Study. 2018 IEEE/ACM 10th International Workshop on Modelling in Software Engineering (MiSE).

[35] Sparks, Geoffrey. (2001). Database Modelling in UML. Methods and Tools 9.1. (2001). p 10-23.

[36] Clyde, Alexander. (2019). PHP: A Step by Step Guide from Beginner to Expert (Learn PHP in 2 Hours and Start Programming

134 International Journal of Web Applications Volume 11 Number 4 December 2019 
Today). Independently Published. ISBN : 978-1078335126

[37] Mehta, Chintan. (2018). My SQL 8 Administrator's Guide (Effective Guide Administering High Performance My SQL 8 Solutions ). Packt Publishing

[38] Pichler., Roman. (2010). Agile Product Management With Scrum: Creating Product that Customer Love. New York : Addison Wesley.

[39] Deemer, Pete. (2012). Lightweight Guide To Theory and Practice of Scrum, Version 2.0. Info Queue.

[40] Andreasen, Sieker, Morten. (2007). What Happen to Remote Usability Testing?. Proceedings of the SIGCHI Conference on Human Factors in Computing System - CHI '07. p 1405.

[41] Rubin, J., Chisnell, D. (2008). Handbook of Usability Testing. Willey Publishing Inc. Canada. 